Research Article

\title{
A Combined HOTS-Based Assessment/STEM Learning Model to Improve Secondary Students' Thinking Skills: A Development and Evaluation Study
}

\author{
Undang ROSIDIN ${ }^{1}$, Agus SUYATNA ${ }^{2} \&$ Abdurrahman \\ ABDURRAHMAN ${ }^{3}$
}

Received: 17 February 2019 Accepted: 2 June 2019

\begin{abstract}
A STEM learning model is believed to be able to improve students' performance in learning physics significantly including Higher Order Thinking Skills (HOTS). These skills covered the capability to analyze, evaluate, and create which can be boosted by implementing a right learning model, material, and assessment. This study aims to develop and evaluate a combined HOTS-based assessment/STEM learning model to enhance students' thinking skills. A proposed model was designed by follow the seven steps of Borg \& Gall research and development. There are 2424 eleventh graders of SMAN 1 Kotabumi at North Lampung and 30 tenth graders of SMA YP Unila at Bandar Lampung involved in limited and field trial, respectively. The impact of this model was evaluated by identifying the normalized average gain of pretest-posttest and significance test compared to a conventional STEM model. The results showed that t-value of experimental, control, and comparison of these two classes are 23.29, 13.58, and $4.63(\mathrm{p}<0.001)$, respectively which confirm a better improvements of thinking skills performed by proposed model.
\end{abstract}

\section{Keywords:}

STEM learning model, HOTS-based assessment, research and development, secondary students

\section{To cite this article:}

Rosidin, U., Suyatna, A. \& Abdurrahman, A. (2019). A Combined HOTSBased Assessment/STEM Learning Model to Improve Secondary Students' Thinking Skills: A Development and Evaluation Study. Journal for the Education of Gifted Young Scientists, 7(2), 435-448. DOI: http://dx.doi.org/10.17478/jegys.518464

\footnotetext{
${ }^{1}$ Faculty of Teacher Training and Education, University of Lampung, Indonesia. E-mail: undangros@yahoo.com / ORCID No: 0000-0003-1589-2403

${ }^{2}$ Faculty of Teacher Training and Education, University of Lampung, Indonesia. E-mail: asuyatna@yahoo.com / ORCID No: 0000-0001-7092-8021

${ }^{3}$ Faculty of Teacher Training and Education, University of Lampung, Indonesia. E-mail: sammy-girly@mail.ru / ORCID No: 0000-0003-4289-6557
} 


\section{Introduction}

Thinking skill is an integrated process to study and understand the learning material. The thinking skills are divided into two, the first is lower order thinking (LOT) which includes the ability to remember, understand, and apply; the second is higher order thinking (HOT) which includes the ability to analyze, evaluate, and create (Anderson \& Krathwohl, 2001). Research by Barnett and Francis (2012) showed that questions at the level of HOTS encourage students to think deeply about the learning material (Barnett \& Francis, 2012). Development of science and technology requires students to have a variety of thinking skills.

In reality, the thinking skills of Indonesian students were still low as the results of the TIMSS (Trends in International Mathematics and Science Study) and PISA (Program for International Student Assessment), especially in science. The results of TIMSS 2015 showed that Indonesian ranked 45th out of 48 countries in student's science literacy with score of 397. Moreover, the ability to answer the questions using tables or graphics only reached 4 percent of the overall true answers. The same condition also occurred in the latest PISA in 2015. Indonesia was ranked 69 out of 76 countries in students' science literacy and it was still low compared to the average OECD score (OECD, 2015). This information indicate that HOTS of Indonesian students need to be trained.

Higher order thinking is a process that involves mental operations such as classification, induction, deduction, and reasoning (Sastrawati, Rusdi, \& Syamsurizal, 2011). The basic principle to assess students' HOTS is the ability to use tasks that require knowledge and skills in new situations (Nitko \& Brookhart, 2011). The assessment principle and standard emphasize two main ideas i.e the assessment must increase students' learning and must be considered as a valuable means to make learning decision (Van de Walle, 2007). One of the techniques to do this is by using sets of items that depend on the context and involve critical thinking, problem solving, and creativity skills (McNeill, Gosper, \& Xu, 2012). According to the revised Bloom's taxonomy, thinking skills were divided into six levels, namely memory, comprehension, application, analysis or synthesis, evaluation, and creation (Syafa'ah \& Handayani, 2015). In the case of HOTS, Bloom's taxonomy is used before the revision stage. It is used in the application, analysis, synthesis, evaluation, and creation stages (Guo et al., 2008; Zheng et al., 2008). The indicators to measure HOTS (Krathwohl, 2002) are described in table 1. 


\section{Table 1.}

The Description of Indicators in Measuring HOTS

\begin{tabular}{|c|c|}
\hline Indicators & Description \\
\hline Analyzing & $\begin{array}{l}\text { a. Analyzing the information and dividing or arranging the } \\
\text { information into smaller parts to know its pattern or } \\
\text { correlation } \\
\text { b. Knowing as well as differentiating causal factor and } \\
\text { effect of hard scenario } \\
\text { c. Identifying / formulating questions }\end{array}$ \\
\hline Evaluating & $\begin{array}{l}\text { a. Giving an assessment towards solution, idea, and } \\
\text { methodology by using suitable criteria or the existing } \\
\text { standard to make sure its effectiveness score and } \\
\text { benefit. } \\
\text { b. Making a hypothesis, criticizing, and do testing } \\
\text { c. Receiving a statement based on the decision criteria }\end{array}$ \\
\hline Creating & $\begin{array}{l}\text { a. Making a generalization of an idea or point of view } \\
\text { towards something } \\
\text { b. Designing a way to solve the problem } \\
\text { c. Coordinating elements or parts into a new structure } \\
\text { which never existed before }\end{array}$ \\
\hline
\end{tabular}

HOTS is a thinking skill which needs not only remembering ability but also other higher abilities including analyzing, evaluating and creating which can be enhanced using STEM (Science, Technology, Engineering, and Mathematics) approach. The term STEM is introduced by NSF (National Science Foundation) of the united states in 1990; it stands for "Science, Technology, Engineering, \& Mathematics" (Sanders, Kwon, Park, \& Lee, 2011). Becker \& Park (2011) explained that STEM was one of the teaching approaches which integrate some disciplines such as sciences, technology, and mathematics and encourage the students to understand those fields. STEM can be developed if it is correlated with the environment which results from learning from real-world experienced by students in their daily life (Subramaniam, Ahn, Fleischmann, \& Druin, 2012). It means that by using the STEM approach, students do not only memorize the concept but also understand science concepts related to daily life.

Morrison (2006) explained that a student who learned by using STEM approach would(1) be able to solve a puzzle problem, (2) have the knowledge to conduct an investigation in solving a problem, (3) be able to decide the need and be creative in designing solution to a problem, (4) be able to develop himself to have esteem and work in certain times, (5) be able to think logically, (6) have ability and able to develop it appropriately(Morrison, 2006). All of those can happen due 
to the integration of STEM is directional from many disciplines that are used to solve the problem in real life (Sanders, 2009). Therefore, learning through the integration of STEM can make the students more ready to work in the field (Brown, Brown, Reardon, \& Merrill, 2011) and can increase the interest and achievement in the field of mathematics and sciences (Stohlmann, Moore, \& Roehrig, 2012).

In addition to the implementation of the right learning approach, the use of teaching materials must conform in order that the thinking skills of students can be trained. One of the teaching materials to help training student's HOTS and as an assessment that can be used to assist students in improving their high-level thinking skills is a student worksheet (Kristianingsih, Wijayati, \& Sudarmin, 2016). This study aimed to develop a combined HOTS-based assessment/STEM learning model and evaluate its impact to students' thinking skills.

\section{Methods}

\section{Research Model}

This research was conducted in two phases of development and measurement. In the first phase, we developed the assessment for learning which consisted of multiple choices and essay questions and the second phase we applied the assessment to measure student's HOTS. The model was designed by following the seven steps of some researcher' study and development scheme which consist of (a) researching and collecting information, (b) planning, (c) developing an early product, (d) limited try out, (e) revising early product, (f) field try out, and (g) revising last product.

\section{Sample}

The proposed learning model and instruments were tested to students at SMA YP Unila Bandar Lampung. The limited tries out phase involved 24 eleventh graders of SMA N 1 Kotabumi, North Lampung, Lampung. While the field tries out phase involved 30 tenth graders of SMA YP Unila Bandar Lampung, Lampung.

\section{Data Collection Tools}

In each meeting at the development stage, students were given STEM-based learning with worksheets, and at the end of learning they were given some multiple-choice questions and a description of the subject matter of pressure, Pascal's Law, and the Law of Archimedes. The preliminary research data in the phase of researching and collecting information were obtained by using questionnaire. The validation of each question and the validation of student's worksheet data were also obtained using questionnaires. The data of reliability and students' higher order thinking skill enhancements were obtained by using HOTS instrument that had been developed in this research. 


\section{Data Analysis}

The students' answers were evaluated to measure their development of higher order thinking skills in order to determine the effectiveness of the instrument as assessment for learning to train student's HOTS. The last stage is to improve or enhance the appropriate product validation based on the results from field try out stage.

The content validity data were analyzed and interpreted qualitatively to determine the feasibility of develop products. Furthermore, the reliability test was conducted to describe the consistency of the research instrument used as a data collecting tool. The reliability test was done by using Alpha Cronbach formula. The analysis of product reliability was done by using SPSS 17 software which then interpreted by using a degree of reliability evaluation tool according to Guilford (1956).

Analysis of students' high-order thinking skills was known from the pretestposttest score and the mean value of gain analysis. Pretest-posttest score data for each control class and experimental class were analyzed using inferential statistic test with paired sample t-test technique to see the improvement of students' higher order thinking skill. The students' pretest-posttest scores were also analyzed using descriptive statistics to calculate the gain values in each control and experiment class. The gain value in the experimental and control classes were analyzed using inferential statistic through independent sample normal-test to see the comparison of the higher order thinking skill level of the students on both classes.

\section{Results and Discussion}

\section{Instrument and Learning Model Development}

The research was conducted from mid-semester to the end of November 2016. Then, the revised questions were tried out to measure student's HOTS level. The expert judgment was done to know the validity of question, and limited try out was performed to know reliability, power balance, and the level of difficulty of the questions. The result of question validity by validator revealed as much as 81 with the valid criterion. The results of the reliability of the test instrument were 0.65 for multiple choices and 0.71 for essay which indicated the high reliability of instrument.

Reliability score of multiple choice tests was 0.65 which belongs to the high category, and reliability score of the essay test was 0.71 which belongs to high category $\mathrm{R}$-table value for this study is 0.345 . By comparing the $\mathrm{r}$-table and $\mathrm{r}$ critical values, it is obtained a reliable result if $r$-critical $>r$-table. The results of difficulty level and power balance of multiple-choice question revealed difficulty level from 15 questions tested; there were 1 difficult question, 10 common questions, and 4 easy questions. Meanwhile, for power balance, there were 7 
questions accepted, 6 questions were accepted with revision, and 2 were rejected. Meanwhile, the results of the difficulty level and power balance of essay question revealed 15 questions with the medium difficulty level. For power balance, there was 1 question accepted, 10 questions were accepted with revision, and 4 questions were rejected. Then, the revision of the questions was done resulting 13 multiple choice questions and 10 essay questions which would be tried out.

The validity of student's worksheet score from expert judgment was 3.18 which belongs to a good category and the design score from the expert was 3.28 which belongs to the excellent category. Besides that, based on the percentage of $\mathrm{N}$-gain, it was found that student's STEM-based worksheet product which has been developed effectively can be used in fluid static learning. After trying out, it would reveal the last product that is student's STEM-based worksheet which can be used to train student's HOTS on the fluid static material. The worksheet is suitable to be used in learning to develop student's HOTS.

Field try out was done in 4 meetings. In the first meeting, a pretest was done before learning started to see students prior ability. Then, in the learning, a step, a practicum of hydrostatic pressure was done by using the developed student's STEM-based worksheet. The use of student's worksheets intended to help students in developing their HOTS during learning. Some HOTS questions about hydrostatic pressure were given at the end of the learning process. The following are some of the HOTS test items included in the worksheet.

\section{Table 2.}

Test Items with HOTS Indicators

Indicators
Analyzing
When you are ice skating, you are wearing specially designed
shoes that have blades on the bottom parts of the shoes (see
image 2). You will be able to skate through ice without the fear
of falling. Have you ever considered why the ice skating shoes
are designed like that? Why do ice skaters could skate through
the ice without falling? Please write your arguments.


Creating

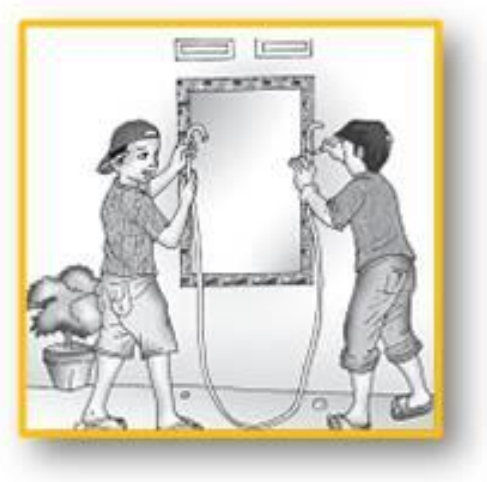

The picture shows two handymen who are placing a window using a water-filled hose. The purpose of using the hose is to measure the height of the window. In your opinion, how could a hose be used to help measuring the height of the window? If two types of liquid with different density are used, can it still be used to help to measure the height of the window? Elaborate your answer.

The second meeting Pascal law practicum was done by using student's STEMbased worksheet product which has been developed. Some HOTS multiple choice and essay questions about Pascal law were given at the end of the learning process. In the third meeting, Archimedes law practicum was done by using student's STEM-based worksheet product which has been developed. Some HOTS multiple choice and essay questions about Archimedes law were given at the end of the learning process. HOTS multiple choices and essays questions were tested in the STEM learning on the control class and the experimental class. The control class using a conventional STEM model and the experimental class using a combined HOTS-based assessment/STEM learning model. A proposed model was presented in Figure 1. 


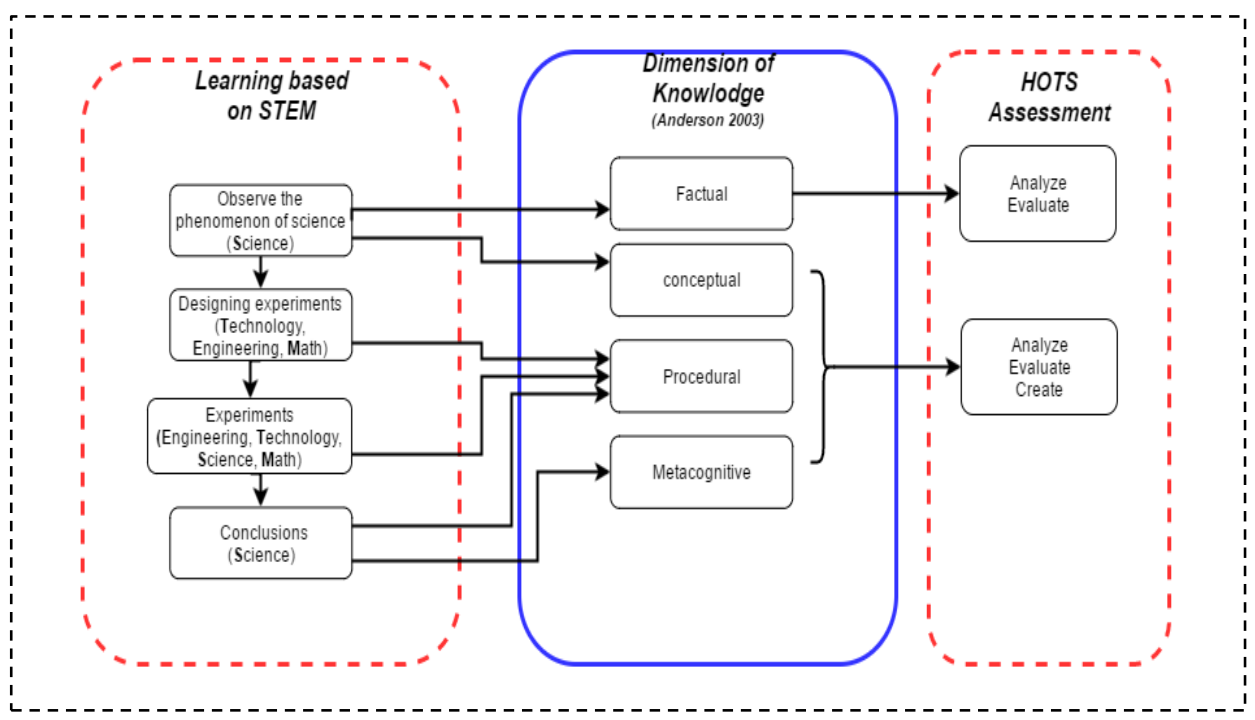

\section{Figure 1.}

A Combined HOTS-Based Assessment/STEM Learning Model Scheme

The development of the student's higher order thinking skills required the appropriate learning model and assessment. Figure 1 showed the framework assessment according to STEM-HOTS learning model as the integration of learning science, technology, engineering, and mathematics. This learning model design was conducted in this research. The improvement of students' higher-order thinking skill was known through the quasi-experimental design technique in the form of pretest-posttest with control group design.

\section{Model Evaluation}

A proposed learning model was evaluated by a sets of statistical judgment based on pretest and posttest data. Figure 2 showed average of pretest and posttest score between (a) control and (b) experimental class. It showed an improvement compared to pretest result after 2 months experiment at the control class. each student's test reports improved (upward lines), and only 1 student who did not improve (flat line). At the control class, it was found that the teaching and learning process by using STEM can increase the score of student test results. This indicated that the teaching and learning process by STEM is effective to increase students understanding of the subject is given in class. 

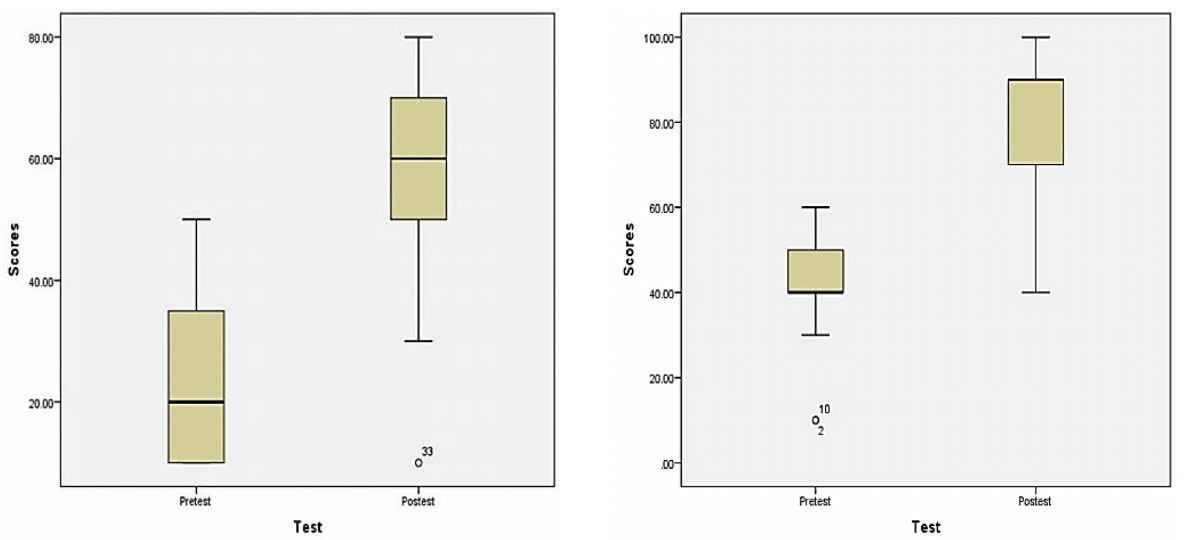

Figure 2 .

The Box Plot Chart Between Pretest and Posttest Results in (a) The Control Class and (b) The Experimental Class

Figure 3(a) shows that the agreement of the pretest and the posttest statically showed that $95 \%$ of the posttest result occurred in a diagonal line (5\%). It showed that there was an improvement from the posttest compared with the pretest. The mean difference between posttest and pretest was 32.50. Moreover, its standard deviation was 10.6992, and the maximum difference was 50. The Paired t-test obtained $\mathrm{t}$-value $=13.58$ with $\mathrm{p}$-value $<0.0001$. It means that the test was very significant and there was a significant improvement store.

Figure 3(b) show that the agreement of pretest and posttest showed that 100\% of the posttest result occurred in a diagonal line. It showed that there was an improvement from the posttest compared to the pretest. At the experimental class, it was found that the teaching and learning process by using STEM can increase the score student's test results. This indicated that the teaching and learning process by STEM is effective to increase the students understanding of the subject is given in class. The mean difference between posttest and pretest was 39.05. Moreover, its standard deviation was 7. 68, and the maximum difference was 30 . The Paired t-test obtained $\mathrm{t}$-value $=23.29$ with $\mathrm{p}$-value $<0.0001$. It means that the test was very significant and there was a significant improvement. 

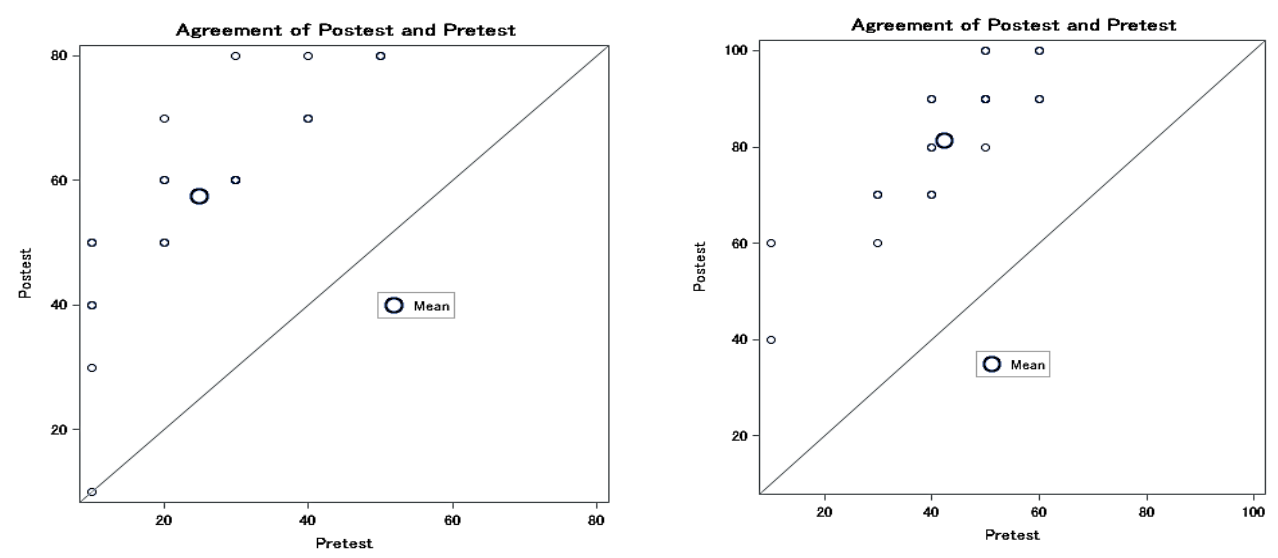

Figure 3.

The Agreement Between Pretest and Posttest in (a) The Control Class and (b) The Experimental Class

The field tests conducted at the experimental class and the control class for 2 months. Based on figure 4, the results of this field test showed that the two gain distributions had different mean scores and had unequal distributions. Moreover, the gained mean score in the experimental class was 0.71 , and the gained means score in the control class was 0.45 . The difference means scores test showed in Table 3 that the t-test $=4.63$ with $\mathrm{p}$-value $<0.0001$. It means that the gained score of the experimental class and the control class was significantly different and the gained score in the experimental class was higher than in the control class.

A combined HOTS-based assessment/STEM learning model is designed to train students level of thinking which composed by the ability to (1) transfer a concept to the other, (2) process and apply information, (3) find a relationship between ideas, (4) use information to solve problems, and (5) explore idea and a concept critically. This model is very important for learning science because a proposed model requires students applying their existing concept and experience in science, technology, engineering, and mathematics together to solve real problems in the environment (Basham \& Marino, 2013; Asghar et al., 2012; Becker \& Park, 2011; Meyrick, 2011; Wang, Moore, Roehrig, \& Park, 2011). One of the things that is a weakness in todays' teaching and learning activities is the lack of relevance between the concepts of science acquired with personal experiences. Learning science should provide explicit experience to students to engage tactically and kinesthetically in learning. Students' engagement in hands-on activities are able to remember the concept better than their peers who are not engaged (Satterthwait, 2010). Moreover, this STEM learning gives assignments to train the students' ability to write, categorize, compare, and differentiate ideas and theories, and problem solving in a complex situations. Students' HOTS can be increased significantly by involving students in a challenging task which requires the use of 
their existing concept to be applied in new situations (Nitko \& Brookhart, 2011; Lewis \& Smith, 1993).

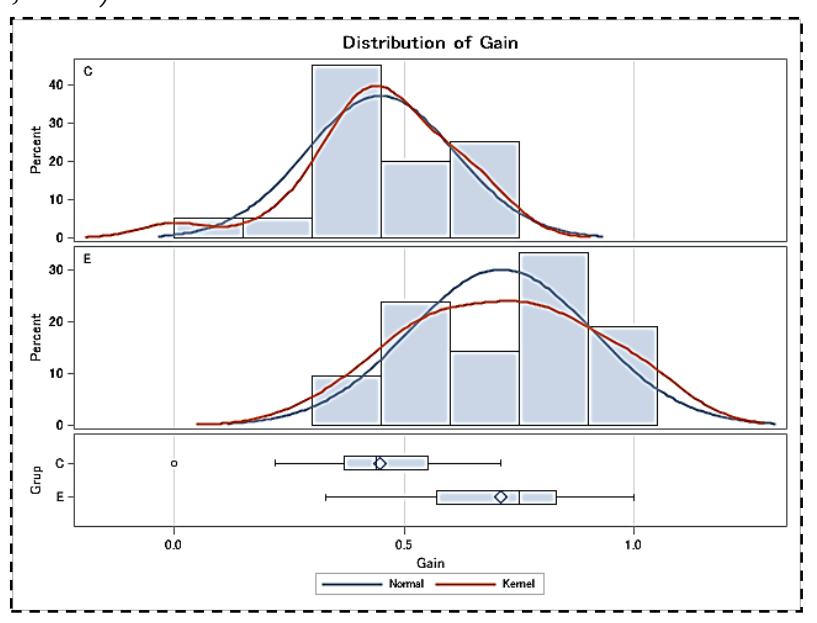

Figure 4.

The Distribution of Gain Chart

Based on the result, it showed that STEM learning affected student learning improvement in the control class and the experimental class. It was because the STEM learning has been designed with student's learning tools that train the student's HOTS. HOTS mean an ability to think in higher order level which are not merely recall, restate, or recite, but also the ability to (1) transfer one concept to the other, (2) process and apply information, (3) find a relationship from many difference information, (4) use information to solve some problems, and (5) explore idea and information critically. In line with Kaya \& Aydin (2016), it is expected to improve higher order thinking skills (HOTS) by developing communication in class through discussion and mathematical activity. Those are performed to know the application and the effects of scientific communication on student's HOTS. The mathematical communication and discussion are expected to be a base to develop student's HOTS ability and its understanding.

STEM learning in the experimental class improved the learning outcomes better compared to the control class. It was because the STEM learning in the experimental class was guided by the learning assessment with the HOTS questions instrument. The skill as creative thinking, critical analysis, problemsolving, and visualization is part of Higher Order Thinking Skills (HOTS). The skills involve the ability to categorize, compare, and differentiated ideas and theories, ability to write, and problem-solving ability. Higher order thinking skill is the process of thinking that occurs at a high level of the cognitive process. The basic principle in studying the ability to apply higher-order thinking is the use of assignments which need knowledge and skills in a new situation. Therefore, the 
student's learning outcomes there are more optimal as the learning period was conducted by combining the assessment for learning STEM with HOTS questions.

\section{Conclusion}

Based on the results of this research, it can be concluded that the learning process through STEM has an effect of increasing the student's performance test both in the control class or the experimental class. In the learning process through STEM, the average gained score in the experimental class was better than the average gained score in the control class. The STEM learning process designed in this model is effective to train students' HOTS effectively. This research recommend teachers and educational practitioners to use a combination of STEM learning approach with HOTS assessment as an alternative strategy to improve the students' thinking skills.

\section{Biodata of the Authors}

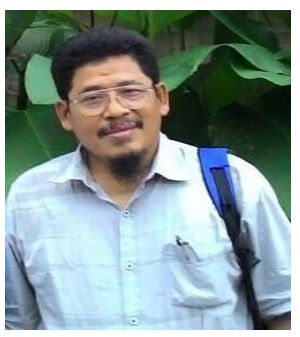

Undang Rosidin is a Senior Lecturer of Physics Education, Faculty of Teacher Training and Education, University of Lampung, Indonesia. He was born in Ciamis, Indonesia and completed his doctoral degree at Universitas Negeri Yogyakarta in 2008 with research field in educational evaluation. His research intereset are assessment and evaluation of science education, higher order thinking skills, STEM learning model, and other areas in the field of education. Affiliation: Department of Physics Education, Faculty of Teacher Training and Education, University of Lampung, Bandar Lampung, Lampung Province, Indonesia. E-mail: undangros@yahoo.com Phone: (+62)81379244667

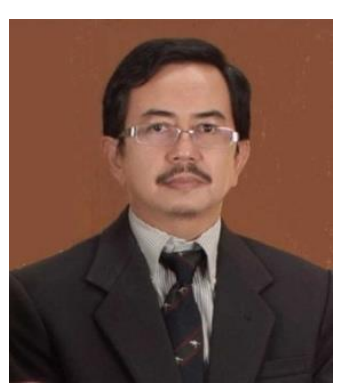

Agus Suyatna was born in Banjarmasin, Indonesia. He is a Professor in Science Education, Faculty of Teacher Training and Education, University of Lampung, Indonesia. His doctoral degree was completed in Indonesia University of Education, 2007. His research areas are science education, higher order thinking skills, learning model and strategy development, computer-based learning, etc.

Affiliation: Department of Physics Education, Faculty of Teacher Training and Education, University of Lampung, Bandar Lampung, Lampung Province, Indonesia. E-mail: asuyatna@yahoo.com

Phone: (+62)85220045573



Abdurrahman was born in Rangkasbitung, Indonesia. His doctoral program is completed from Department of Science Education, Indonesia University of Education in 2010. He is a lecturer of physics education at Faculty of Teacher Training and Education, University of Lampung, Indonesia. His research focuses on STEM education, 
science literacy, higher order thinking skills, multiple representations and etc.

Affiliation: Department of Physics Education, Faculty of Teacher Training and Education, University of Lampung, Bandar Lampung, Lampung Province, Indonesia. E-mail: abdurrahman.1968@,fkip.unila.ac.id Phone: (+62)8127911494

\section{References}

Anderson, O. W., \& Krathwohl, D. R. (2001). A Taxonomy for Learning Teaching and Assessing. Newyork: Addison Wesley Longman.

Barnett, J. E., \& Francis, A. L. (2012). Using Higher Order Thinking Questions to Foster Critical Thinking: A Classroom Study. Educational Psychology, 32(2), 201-211. https://doi.org/10.1080/01443410.2011.638619

Becker, K. H., \& Park, K. (2011). Integrative Approaches among Science, Technology, Engineering, and Mathematics (STEM) Subjects on Students Learning: A Meta Analysis. Journal of STEM Education: Innovations and Research, 12(5).

Brown, R., Brown, J., Reardon, K., \& Merrill, C. (2011). Understanding STEM: Current Perceptions. Technology and Engineering Teacher, 70(6), 5-9.

Guilford, J. . (1956). Fundamental Statistic in Psychology and Education.3rd Ed. New York: McGraw-Hill Book Company, Inc.

Guo, S., Freeman, S., Lawhorn, J., \& Zheng, A. (2008). 1018 Free Access to Landsat Imagery Teach by the Book Science Education: Science, 320(5879), 1011-1012. https://doi.org/10.1126/science.320.5879.1011a

Hake, R. R. (2001). Lesson from the Physics-Education Reform Effort. Conservation Ecology, $1-61$.

Kaya, D., \& Aydin, H. (2016). Elementary Mathematics Teachers' Perceptions and Lived Experiences on Mathematical Communication. Eurasia Journal of Mathematics, Science \& Technology Education, 12(6), 1619-1629. https://doi.org/10.12973/eurasia.2014.1203a

Krathwohl, D. R. (2002). A Revision of Bloom's Taxonomy: An Overview. Theory Into Practice, 41(4).

Kristianingsih, D. D., Wijayati, N., \& Sudarmin. (2016). Pengembangan LKS Fisika Bermuatan Generik Sains untuk Meningkatkan Higher Order Thinking (HOTS) Siswa. Journal of Innovative Science Education, 5(1), 73-82.

McNeill, M., Gosper, M., \& Xu, J. (2012). Assessment Choices to Target Higher Order Learning Outcomes: the Power of Academic Empowerment. Research in Learning Technology, 20(0). https://doi.org/10.3402/rlt.v20i0.17595

Morrison, J. (2006). TIES STEM Education Monograph Series: Attributes of STEM Education. Baltimorc: MD: TIES.

Narayanan, S., \& Adithan, M. (2015). Analysis Of Question Papers In Engineering Courses

With Respect To Hots (Higher Order Thinking Skills). American Journal of Engineering Education (AJEE), 6(1), 1. https://doi.org/10.19030/ajee.v6i1.9247

Nitko, A. J., \& Brookhart, S. M. (2011). Educational Assessment of Student. Boston: Pearson Education.

OECD. (2015). Pisa 2015.

Sanders, M. (2009). STEM, STEM Education, STEMmania. The Technology Teacher, 68(4). 
Sanders, M., Kwon, H., Park, K., \& Lee, H. (2011). Integrative STEM (Science, Technology, Engineering, and Mathematics) Education: Contemporary Trend and Issues. Secondary Education, 53(3).

Sastrawati, E., Rusdi, M., \& Syamsurizal. (2011). Problem-Based Learning, Strategi Metakognisi dan Keterampilan Berpikir Tingkat Tinggi Siswa. Tekno-Pedagogi, 1(2), 1-14. Stohlmann, M., Moore, T. J., \& Roehrig, G. H. (2012). Considerations for Teaching Integrated STEM Education. Journal of Pre-College Engineering Education Research, 2(1), 2834. https://doi.org/10.5703/1288284314653

Subramaniam, M. M., Ahn, J., Fleischmann, K. R., \& Druin, A. (2012). Reimagining the Role of School Libraries in STEM Education: Creating Hybrid Spaces for Exploration. The Library Quarterly, 82(2), 161-182. https://doi.org/10.1086/664578

Syafa'ah, H. K., \& Handayani, L. (2015). Pengembangan Metacognitive Self-Assesment untuk Mengukur Keterampilan Berpikir Evaluasi dalam Membaca Teks Sains Berbahasa Inggris. UPEJ Unnes Physics Education Journal, 4(1), 43-48. https://doi.org/10.15294/UPEJ.V4I1.4742

Van de Walle, J. A. (2007). Elementary and Middle School Mathematics: Teaching Developmentally, (6th ed.). Boston: Pearson Education, Inc.

Zheng, A. Y., Lawhorn, J. K., Lumley, T., \& Freeman, S. (2008, January). ASSESSMENT: Application of Bloom's Taxonomy Debunks the "MCAT Myth." Science, 319(5862), 414-415. https://doi.org/10.1126/science.1147852 